\title{
Microscopic Morphology and Testis Morphometry of Captivity-bred Adult Bullfrogs (Lithobates catesbeianus Shaw, 1802)
}

\author{
Jaqueline Carlos and Sérgio Luis Pinto da Matta* \\ Laboratório de Biologia Estrutura; Departamento de Biologia Geral; Universidade Federal de Viçosa; 36570-000; \\ Viçosa - MG-Brasil
}

\begin{abstract}
The aim of this work was to study the testicular morphometry of captivity-bred adult bullfrogs. Fifteen young adult male were studied, in the rainy season and a lengthy photoperiod. The GSI was established at 0.15\%. The nuclear diameter of germinative and Leydig cells, the nucleolus diameter of Sertoli cells and the area of cysts and tubules were determined and the mean number of ISPC, IISPC and SPT per cyst and the mean number of cysts per tubule was estimated. The nucleoplasmatic proportion of the nucleus of the Leydig cell was $76.22 \%$, indicating less cytoplasmic activity. Eight generations of spermatogonia were found. The spermatogenesis efficiency in meiosis and in mitosis was 63 and 49\%, respectively. The spermatogenesis of bullfrog fited in the pattern of other captivity Anurans, with differences as the morphology of Sertoli and Leydig cells nuclei.
\end{abstract}

Key words: spermatogenesis, Sertoli, Leydig, GSI

\section{INTRODUCTION}

Lithobates catesbeianus, the bullfrog, is a member of the Ranidae family, native to North America (United States and Canada), and has been used in several countries to establish frog farms. Its name was changed from Rana catesbeiana to $L$. catesbeianus, recently (Dubois, 2007).

The bullfrog has sexual reproduction with sexual dimorphism, most evident during the reproductive period. The tympanic membrane diameter in the males is two to three times as big as the eyes. Their thumbs are swollen and velvety on the dorsal surface and they give out sounds (sing) to attract the female for mating (Sadleir, 1973; Lima and Agostinho, 1988; Lima and Agostinho, 1995).
The bullfrog adapts well to captivity and is widely used for human food consumption due to its high nutritional content (Costa, 1992). In experimental research, the bullfrog is an excellent model of laboratory animal.

In São Paulo state, Brazil, reproductive periods of bullfrogs in captivity were observed from September to January and February to mean April (Fontanello et al., 1984; Vizotto, 1986).

Costa (1992) distinguished five stages of testicular development for bullfrog: (1) young, with prevailing primary spermatogonia (ISPG); (2) initial maturation, with beginning of spermatogenic activity and cysts of primary spermatocytes (ISPC); (3) intermediate maturation, with spermatid (SPT) cysts and low

*Author for correspondence: smatta@ufv.br 
spermatozoa (SPZ) in the tubular lumen; (4) advanced maturation with developed testes, filled with SPZ; and (5) exhausted, with no SPZ in the tubular lumen.

The spermatogenesis of Anurans is cystic, with synchronous cells in the same cyst. The germinative cells of the cyst arise from a single ISPG stem cell. This cell undergoes mitosis and gives rise to two secondary spermatogonia (IISPG) cells that proliferate by mitosis, remaining in the same cyst. After several divisions, the IISPG cells become primary spermatocytes that begin meiosis I. At the end of meiosis I the secondary spermatocyte (IISPC) cells are formed. The IISPC gives rise to spermatid cells at the end of the meiosis process. The spermatid differentiate to form spermatozoa (SPZ) through a process called spermiogenesis (Pierantoni, 1999).

The spermatids are exposed in the lumen of seminiferous tubule after the opening of the cysts. Their cell nuclei are elongated and the chromatin condensed. In the SPZ formation, the surplus cytoplasm is lost (Sprando and Russel, 1987).

Morphometry is an important tool for structural biology since it allows quantitative analyses that work with stereology principles and reduce the inaccuracy and subjectivity of morphological analyses (Mandarim-De-Lacerda, 1995). Morphometry applied in descriptive studies is the base for comparisons of the treatment groups in experimental studies. The main measurable parameters are number, area, length, volume, and diameter of structures (Bozzola and Russell, 1998). Its application in testis analysis deepened the comprehension of gonadal dynamics, making a comparison of testicular structure and function possible (Matta et al., 2002). Costa (1992) studied aspects of bullfrog spermatogenesis in the testicular cycle as well as reproductive biology, but did not deal with morphometrical approaches. Partial morphometrical analyses are found in studies realized by Saez et al. (1990) and Fraile et al. (1992) with Triturus marmoratus, Kanamadi and Jirankali (1992) with Polypedates maculatus, Ko et al. (1998) with Rana nigromaculata, Rana rugosa and Rana dybowskii testicular cycles, and Sasso-Cerri et al. (2004) with Rana catesbeiana.

\section{MATERIALS AND METHODS}

Fifteen young adult males were obtained from the Experimental Froggery of the Federal University of Viçosa (2045'14”'S, 4252'53”'W, 648.7m asl), Minas Gerais state, during the rainy period (December, 2000) with high temperatures and long photoperiod. All animals were anesthetized in ice bath for 5-10 minutes. Then the spinal cords were pitched and the frogs were killed.

The body weight (BW) and gonadal weight (GW) were measured on a digital precision scale.

The testes were fixed in $2.5 \%$ glutaraldehyde in $0.1 \mathrm{M}$ sodium phosphate buffer $(\mathrm{pH} 7.4)$ and included in glycol methacrylate (Historesin ${ }^{\circledR}$, Reichert-Jung) following routine procedures. Serial longitudinal sections ( $3 \mu \mathrm{m}$ and $4 \mu \mathrm{m}$ ) were obtained using rotary microtome (Reichert-Jung, Multicut ${ }^{\circledR}$ - 2045) and glass razor, according to MATTA et al. (2002). The sections were stained with $1 \%$ toluidine blue-sodium borate and mounted in Entellan ${ }^{\circledR}$ (Merck).

The nucleus diameters of the spermatogenic and Leydig cells, Sertoli nucleolar cell diameters, and seminiferous tubule and cyst areas were evaluated by image analysis using Image Pro Plus 4.0 software and a BX-50 microscope (Olympus).

Nuclear diameters of the spermatogenic cells (ISPG, IISPG, ISPC, IISPC and SPT) were measured using a 100X objective, $1 \mathrm{X}$ zoom. Thirty counts were realized for each cell type.

The nucleolar Sertoli cell diameters (30 per animal) were measured under a $100 \mathrm{X}$ objective and $2 \mathrm{X}$ zoom.

Thirty cysts of ISPC, IISPC and SPT cell types were measured using 40X objectives, without zoom. The number of the spermatogenic cells (ISPC, IISPC e SPT) per cyst and the Sertoli cells in the wall of these cysts were counted using a 40X objective, without zoom, and manual counter. Ten seminiferous tubules of each animal were chosen randomly. The cysts of these tubules were counted and associated to the different cell types.

The number of cysts counted per animal was ten for each cell type. The seminiferous tubule area was recorded using 30 samples per animal.

The volumetric proportion between the tubular and intertubular compartments was evaluated by the analysis of five sections of entire testes (of five animals) and 20 different fields of the testes of the 10 remaining animals, using grid lines with 494 points in a monitor linked to a microscope Olympus BX 50 (40X objective, without zoom).

The volumetric proportion between interstitial tissue and Leydig cells was obtained by count of 20 areas of intertubular space per animal, using the 
same grid lines. Points on the interstitial tissue and points on Leydig cells were counted. The results were expressed in percentage. Thirty diameters of Leydig cells were measured using a 100X objective, $1 \mathrm{X}$ zoom.

To determine the ratio (\%) between the nucleus and cytoplasm of the Leydig cells, 2000 points on the cytoplasm and nucleus per animal were counted using a 100X objective. The diameters obtained were used for volume calculations. The nuclear, cytoplasmic and cell volume of the Leydig cell per animal were calculated by the formula:

Nuclear volume $=4 / 3 \pi R^{3} \quad$ where, $R=$ nuclear ray

Cytoplasmic volume $=\%$ cytoplasm $\mathrm{x}$ nuclear volume / \% nucleus

Cell volume $=$ nuclear volume + cytoplasmic volume

To evaluate the efficiency of the spermatogenic process, the relations between the total numbers of the different cells of the spermatogenic strain per cyst were estimated. The calculated ratios were: ISPC: IISPC; IISPC: early SPT; ISPC: early SPT; early SPT: ISPC.

Based on the maximum number of ISPCs found in the respective cysts the number of spermatogonial generations was calculated, beginning with the primary spermatogonia.

The Sertoli cell support capacity was determined by the formula:

Support Capacity $=$ number of spermatogenic cells per cyst / nr. of Sertoli cells per cyst

The gonadosomatic index (GSI) was calculated based on the gonadal weight $(\mathrm{GW})$ and body weight (BW) using the following formula:

$$
\mathrm{GSI}=\mathrm{GW} / \mathrm{BW} \times 100
$$

The meiosis index was calculated by the formula: mean number of obtained ISPC / mean number of obtained SPT

The meiosis efficiency was obtained using the formula: Meiosis index - 1 x 100
The mitosis index was calculated using this formula: mean number of obtained ISPC / mean number of expected ISPC.

The mitosis efficiency was obtained using the formula: Mitosis index - 1 x 100.

The data analyses were run on software SAEG 8.0 (Federal University of Viçosa).

\section{RESULTS}

The mean body weight of the bullfrog specimens was $286.94 \mathrm{~g} \pm 62.2$ (mean $\pm \mathrm{SD}$ ), the mean testis weight $0.41 \mathrm{~g} \pm 0.01$ and the mean GSI $0.15 \%$.

The bullfrog's testes are situated laterally on the fat body, ventrally to the kidney (connected to it by the mesorchium). They are ovoid-shaped and the left and right one are equal in size.The testes are surrounded by the tunica albuginea that branches out into the testes constituting the interstitial tissue or intertubular compartment. This tissue, localized between the seminiferous tubules, has lymphatic vessels, blood vessels and connective tissue cell types such as mast cells, macrophage and fibroblasts. The Leydig cells nucleus immersed in interstitial tissues produce the testicular androgen (Fig. 1A). Collecting ducts are found in the intertubular region and have cell walls with epithelial arrangement (Fig. 1B).

The seminiferous tubule wall consists of myoid cells, basal lamina and cysts of reproductive cells in different spermatogenic phases, but at the same development stage within every cyst. The myoid cells had a fusiform nucleus and seemed to encircle the seminiferous tubules (Fig. 1A). The cyst wall was formed by a group of linked up Sertoli cells. The set of cysts delimited the lumen of the seminiferous tubule. The primary spermatogonium (ISPG) was the biggest cell of the spermatogenic strain with a large nucleus with loose chromatin and one or more evident nucleoli (Fig 2A). These cells were detached within the cyst and were distributed all over the seminiferous tubules, without a preferential position. 


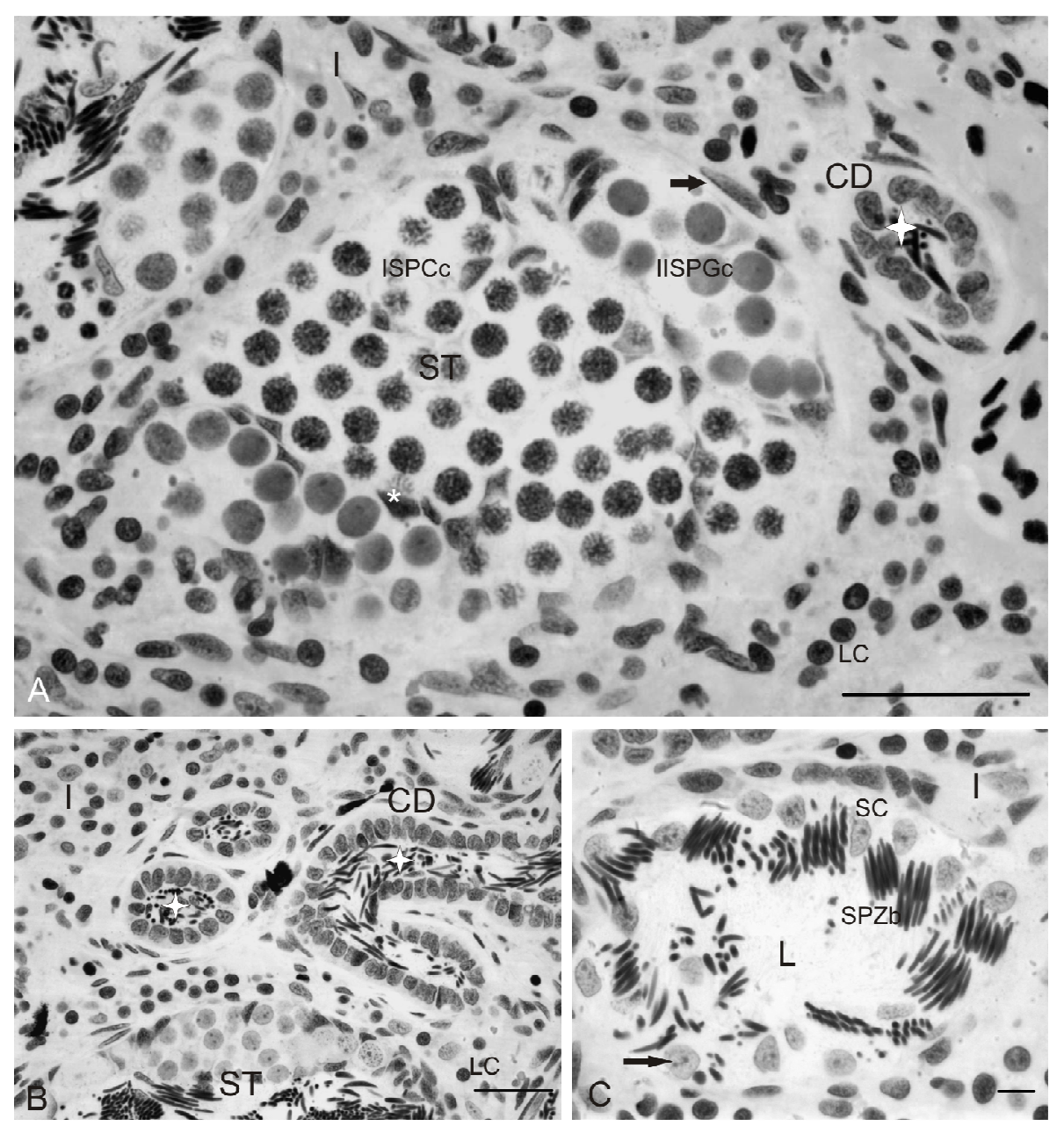

Figure1 - A-C, Light micrographs of cross section of testis of L. catesbeianus bred in captivity, stained with toluidine blue.-A-B, star indicate the presence of spermatozoa in the lumen of collect duct. -A, asterisc indicates Sertoli cell and the arrow indicates myoid cell. -C, the arrow indicates the nucleolus of the Sertoli cell. Abbreviations: I= Intertitium, ST= Seminiferous tubule, $\mathrm{LC}=$ Leydig cell, ISPCc $=$ Cyst of primary spermatocyte, IISPGc $=$ Cyst of secondary spermatogonia, $\mathrm{CD}=$ Collect duct, $\mathrm{L}=$ Lume of seminiferous tubule, $\mathrm{SPZb}=$ Bundle of Spermatozoas, $\mathrm{SC}=$ Sertili cell. Scale bars: $\mathrm{A}=50 \mu \mathrm{m}, \mathrm{B}=40 \mu \mathrm{m}, \mathrm{C}=$ $10 \mu \mathrm{m}$.

Secondary spermatogonia (IISPG) had smaller nuclei than ISPG (Fig. 2B). The chromatin can be from loose to condensed, at times permitting a visualization of the nucleolus, at times not. Due to the great number of mitotic divisions, the variation in nucleus morphology is high. These cells are found in variable number in cysts. They undergo successive mitosis to produce primary spermatocytes (ISPC) that begin the meiosis stage. In the ISPC, the nucleus is often seen in prophase I, with more evident and paired chromosomes that form synaptonemal complexes (Fig. 2C). Secondary spermatocytes (IISPC) present more condensed chromatin and are very difficult to be seen since this division stage is very short (Fig. 2D).

The nuclear morphology of spermatids (SPT) in the spermiogenic process is typically variable, ranging from round cells with loose chromatin to elongated forms with condensed chromatin (Fig 2E). 


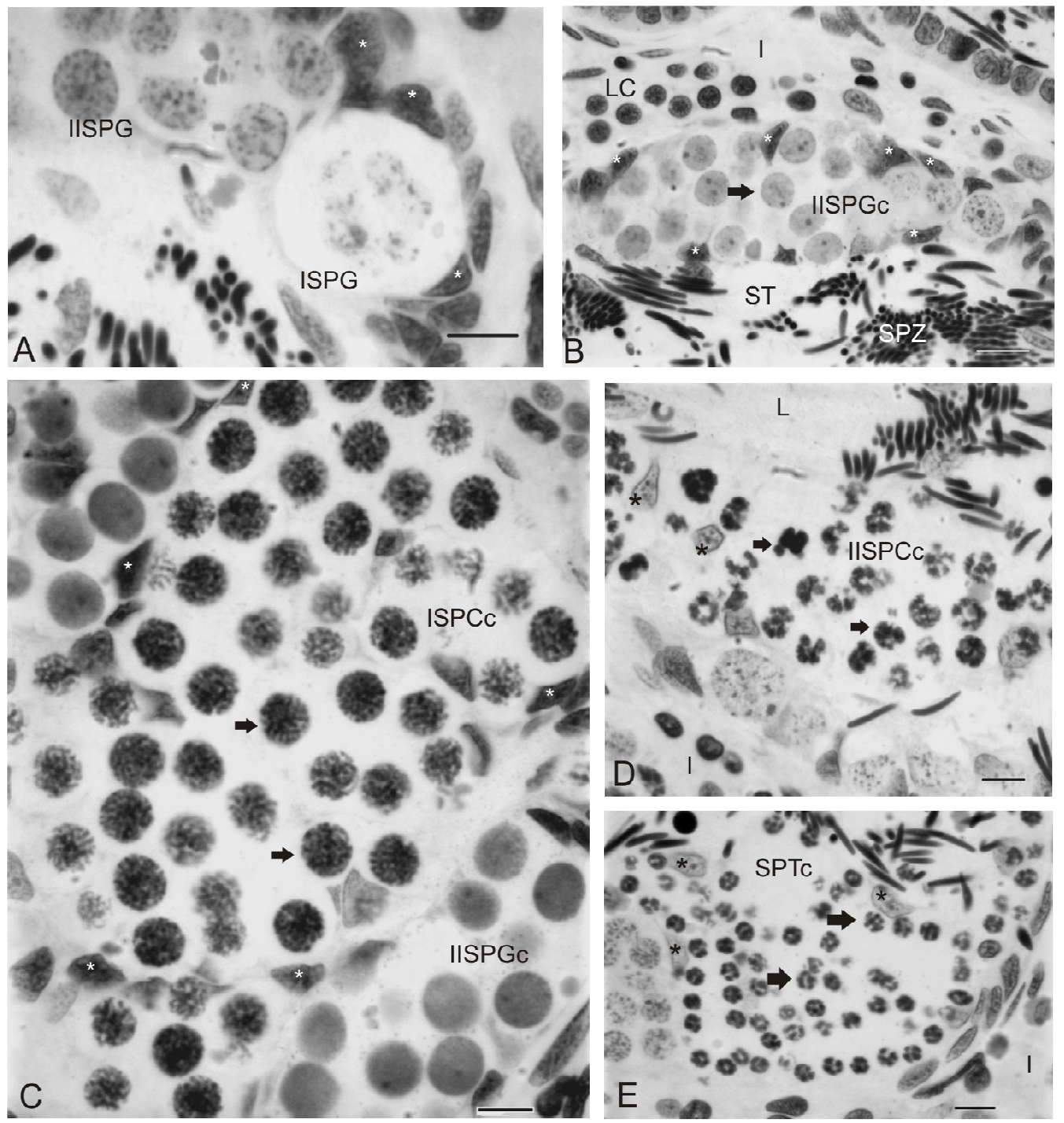

Figure 2 - A-E, Light micrographs of cross section of testis of L. catesbeianus bred in captivity, stained with toluidine blue - A-E, asteriscs indicate the Sertoli cell surrounding the cysts.-B-E, the arrows indicate secondary spermatogonia, primary spermatocyte, secondary spermatocyte and spermatide, respectively. Abbreviations: IISPG= secondary spermatogonia, ISPG primary spermatogonia, I= Intertitium, LC= Leydig cell, ST= Seminiferous tubule, IISPGc Cyst of secondary spermatogonia, SPZ= Spermatozoa, ISPCc $=$ Cyst of primary spermatocyte, IISPCc $=$ Cyst of secondary spermatocyte, SPTc Cyst of spermatide, L= Lume of seminiferous tubule. Scale bars: $\mathrm{A}, \mathrm{D}$ and $\mathrm{E}=10 \mu \mathrm{m}, \mathrm{B}$ and $\mathrm{C}=15 \mu \mathrm{m}$.

Spermatozoa (SPZ) with elongated and highly condensed heads were found in the lumen of seminiferous tubules, coupled to the apical surface of the Sertoli cells grouped in bundles as well as inside the collecting ducts (Fig 1C).

The Sertoli cells have a sometimes irregular pyramidal or ovoid nucleus with a nucleolus that can be visible or not, according to the different chromatin condensation stages. In cysts containing round spermatogenic cells, the Sertoli cell nucleus was pyramidal and dark colored, the chromatin was dense, the nucleolus was not evident and the size was small (Fig. 2A-E). On the other hand, the Sertoli cell that sustained the SPZ bundle presented an ovoid and light-colored nucleus with loose chromatin, an evident nucleolus and greater nucleus size than the cell with the pyramidal nucleus. When the cysts open, the Sertoli cells line 
up side by side containing SPZ bundles fastened to their apical surface (Fig. 1C).

The Leydig cells presented ovoid or round nuclei with variable chromatin density and a not always visible nucleolus (Fig. 1A). These cells appeared either detached or in groups near the blood vessels. The mean nuclear diameter of the spermatogonial cells was $15.19 \pm 0.62$ and $11.56 \mu \mathrm{m} \pm 0.15$, respectively, for ISPG and IISPG. Spermatocytes (ISPC/IISPC) and spermatids presented mean nuclear diameters of $9.55 \pm 0.41,6.98 \pm 0.75$, and $4.81 \mu \mathrm{m} \pm 0.33$, respectively (Fig. 3), whereas the Leydig cell had a nuclear diameter of $5.97 \mu \mathrm{m}$ \pm 0.43 .

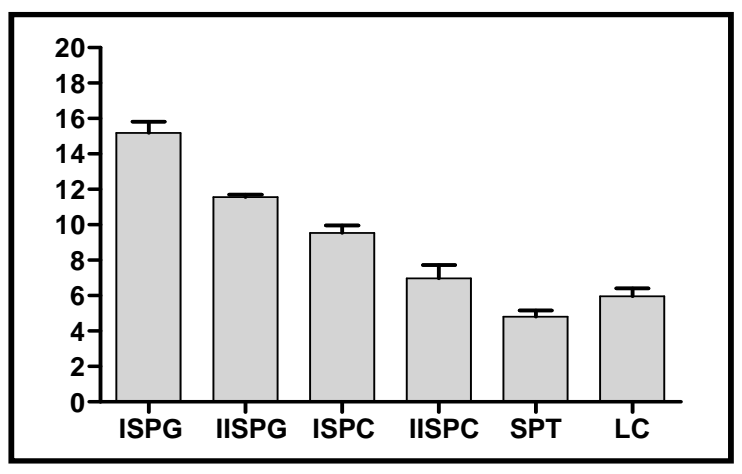

Figure 3 - Nuclear diameter $(\mu \mathrm{m})$ of spermatogenic cells and Leydig cells of $L$. catesbeianus bred in captivity.

The mean area of the seminiferous tubule was 0.54 $\mathrm{mm}^{2}$, varying from 0.19 to $0.68 \mathrm{~mm}^{2}$. The mean area of the ISPC cyst comprised $1,986.4 \mu \mathrm{m}^{2} \pm$ 144.45 and the IISPC cyst area covered $1,934.8$ $\mu \mathrm{m}^{2} \pm 103.8$. Spermatids cysts had a mean area of $1,858.8 \mu \mathrm{m}^{2} \pm 141.8$ The cysts reached their largest size when they contained ISPC cells although their area did not vary much during the spermatogenesis process (Fig. 4).

The total number of cysts of all cell types found per tubule was in the mean 18.75. The mean number of ISPG, IISPG, ISPC, IISPC, and SPT cysts per tubule was $5.79 \pm 2.9,10.1 \pm 3.9,1.34$ $\pm 0.5,0.13 \pm 0.1$ and $2.04 \pm 0.8$, respectively (Fig. $5)$.

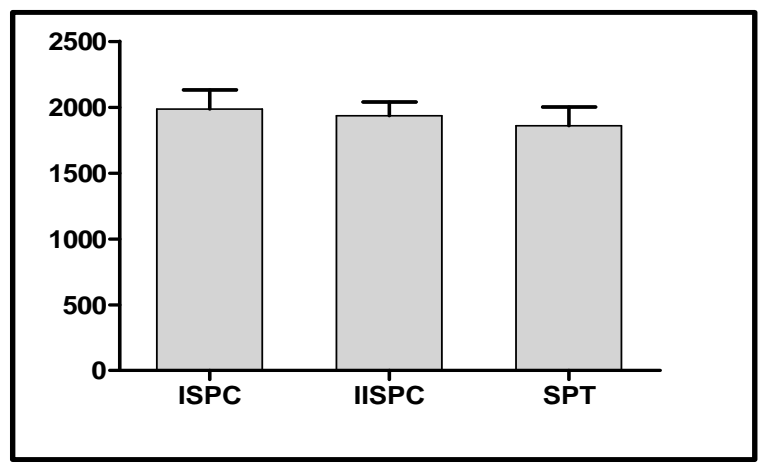

Figure 4 - Cystic areas $\left(\mu \mathrm{m}^{2}\right)$ of different spermatogenic cell types of $L$. catesbeianus bred in captivity. 


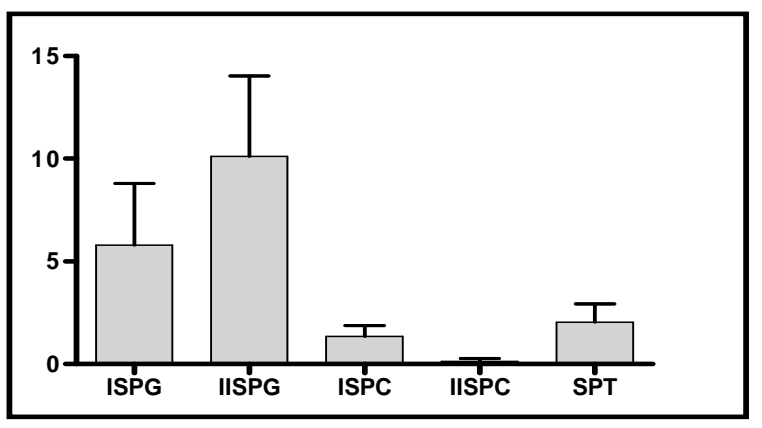

Figure 5 - Number of cysts of different spermatogenic cell types per seminiferous tubule of $L$. catesbeianus bred in captivity.

The mean Sertoli cell support capacity was 5.82 (ISPC), 7.50 (IISPC) and 13.80 (SPT) per cyst of germ cell. The number of spermatocytes (ISPC and IISPC) and spermatids (SPT) per cyst was $124.76 \pm 25.5,183.43 \pm 41.5$ and $341.56 \pm 96.3$. respectively (Fig. 6). The number of Sertoli cells in the wall of ISPC, IISPC and SPT cysts was
21.44, 24.45, and 24.64, respectively.

The volumetric proportion (percentage) of tubular (seminiferous tubules and respective cysts) and intertubular compartments (Leydig cells, connective tissue cells and fibers, and vessels) were $86.18 \pm 3$ and $13.82 \% \pm 3$, respectively (Fig 7).

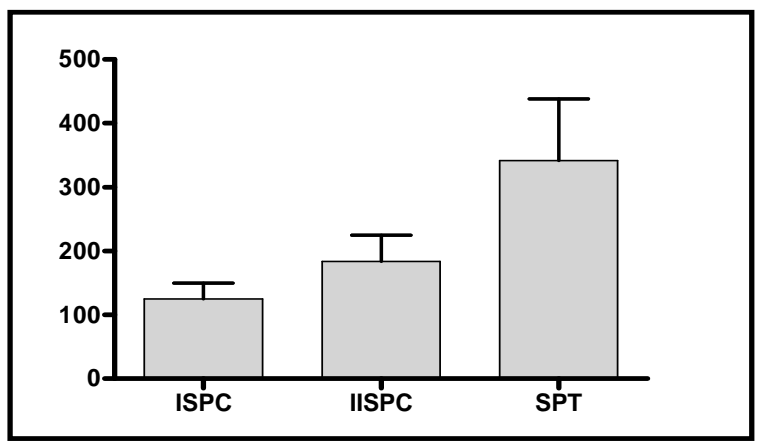

Figure 6 - Total number of spermatogenic cells per cysts of L. catesbeianus bred in captivity.

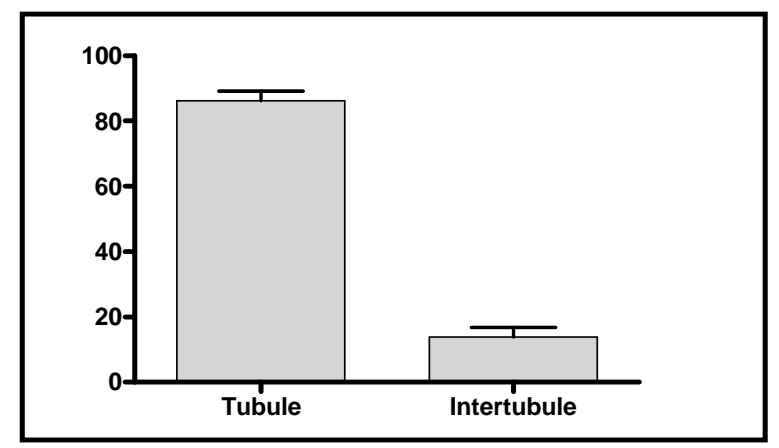

Figure 7 - Volumetric proportion between tubule and intertubule of L. catesbeianus bred in captivity. 
The Leydig cells occupied $27.33 \%$ of the interstitial tissue. The volumetric proportion of blood vessels, lymphatic vessels, cells and fibers of the connective tissue was $72.67 \%$.

The proportion (percentage) between nucleus and cytoplasm (NPR) established for the Leydig cell was $76.22 \%$ for nucleus and $23.78 \%$ for cytoplasm.

Based on the nucleus radius of the Leydig cell and the NPR, the cell volume of the Leydig cells $\left(112.63{\mu \mathrm{m}^{3}}^{3}\right)$ was obtained, of which 85.85 $\mu \mathrm{m}^{3}$ accounted for the nuclear and $26.78 \mu \mathrm{m}^{3}$ for cytoplasmatic volume (Table 1).
Each primary spermatocyte produced 1.5 secondary spermatocytes which in turn produced 1.9 spermatids. Each ISPC cell gave rise to 2.5 SPT (Table 2).

The meiosis index, calculated by the ratio SPT/ISPC, was 0.37 . The spermatogenesis efficiency in meiosis was $63 \%$ from ISPC to SPT. In 75 evaluated cysts the highest number of ISPC per cyst was 240 . As judged by this number there are 8 generations of spermatogonia from the first mitosis until ISPC cell formation.

Table 1 - Morphometrics parameters of Leydig cell of L. catesbeianus bred in captivity.

\begin{tabular}{lcc}
\hline \multicolumn{2}{c}{ Parameter } & \\
\hline Nuclear diameter $(\mu \mathrm{m})$ & $5.97 \pm 0.11$ & \\
cytoplasm vol $\left(\mu \mathrm{m}^{3}\right)$ & 26.78 & $76.22 \%$ \\
nucleus vol $\left(\mu \mathrm{m}^{3}\right)$ & 85.85 & \\
cell vol $\left(\mu \mathrm{m}^{3}\right)$ & 112.63 & \\
\hline
\end{tabular}

Table 2 - Ratio among different spermatogenic cell types of L. catesbeianus bred in captivity.

\begin{tabular}{ll}
\hline Celular types & Ratio \\
\hline ISPC $:$ IISPC & $01: 01.5$ \\
IISPC $:$ SPT & $01: 01.9$ \\
ISPC $:$ SPT & $01: 02.5$ \\
SPT $:$ ISPC & $0.37: 1$ \\
\hline
\end{tabular}

Since the number of cell generations was 8 the expected number for ISPC would be 256 cells. However, the mean number was 124.76. The mitotic index obtained by these data was therefore 0.51 . The spermatogenesis efficiency in mitosis was $49 \%$.

\section{DISCUSSION}

To our knowledge, this is the first investigation to evaluate the principal reproductive morphometric parameters in Anura, approaching germ, Sertoli, and Leydig cell number and morphological characteristics.

The mean body weight of the studied frogs was $286 \mathrm{~g}$ L. catesbeianus. Cultivated under similar conditions in Thailand, the animals attained a mean body weight of $293 \mathrm{~g}$ (Chavadej et al., 2000).
The gonadosomatic index (GSI) of males was low throughout and quite variable in most animals under study. Ko et al. (1998) studied the testicular cycle of three Korean frog species, $R$. nigromaculata, $R$. rugosa and $R$. dybowskii and observed a mean GSI of $0.37 \%$ for the first and $0.58 \%$ for the second species in the same reproduction period, while the GSI of $R$. dybowskii varied considerably within one year.

The mean testes weight of the study animals attained $0.41 \mathrm{~g}$, close to that of Thai bullfrogs whose testes had a mean weight of $0.43 \mathrm{~g}$ (Chavadej et al., 2000). The testes with the same size and oval shape was in line with the description of Costa (1992) for L. catesbeianus, although small differences between the two testes of a single animal were observed in some specimens. Kao et al (1993) found size differences of up to $20 \%$ between the testes of $R$. rugulosa. 
The GSI value for L. catesbeianus in this study $(0.15 \%)$ was equal to the one found for the same species cultivated in Thailand $(0.145 \%)$ in artificial ponds (Chavadej et al., 2000) It corresponded to about half of $R$. nigromaculata and less than a third of the GSI found for $R$. rugosa, though all these indices was very low, especially when compared with females. The values could also be influenced by the photoperiod, latitude and sampling period. It should be taken into consideration that the GSI values also varied considerably from one frog species to another, indicating a certain speciesspecificity.

Microscopically, the L. catesbeianus testes were in agreement with the description given by Costa (1992). The seminiferous tubule wall was formed by a set of cysts whose spermatogenic cells are synchronized in the division process, as mentioned by Pierantoni (1999). All cell types of the spermatogenic process cited by this author were found in this study. This was mainly due to the chosen study period, the summer of the southern hemisphere, which was a time of high gamete production. Pierantoni et al. (2002) described the presence of spermatogonia and spermatozoids only for $R$. esculenta in the same period as used in this study. All cell types are found in L. catesbeianus may be due to the tropical climate of Brazil, which favored continuous spermatogenesis.

Fraile et al. (1989) described primary spermatogonia (ISPG) of marbled newt (Triturus marmoratus) with ovoid nuclei and loose chromatin distribution, similar to bullfrog.

In relation to secondary spermatogonium in marbled newt, Fraile et al. (1989) described small nucleus cells. These authors did however not measure the nuclei. The chromatin distribution of the secondary spermatogonium in $L$. catesbeianus was in line with the description of Fraile et al. (1989), varying from loose to condensed.

The ISPC chromosomes in L. catesbeianus were generally paired and well-distinguished. Fraile et al. (1992) found interstage primary spermatocides with homogeneous chromatin, an evident nucleolus and also in meiosis, with a chromatin that resembled the pattern of the first meiotic division.

Hermosila et al. (1983) and Costa (1992) observed the nucleus of the secondary spermatocide with condensed chromatin in one of the poles, unlike results of the present study. The inclusion in paraffin these authors used, along with the type of fixation, could be reasons for this difference.

The spermiogenesis process can further be analyzed by observations of spermatids with nuclei in different modifications stages. Sprando and Russel (1987) claim that the cyst of $L$. catesbeianus opens up after the spermiogenic process when the spermatozoids were already formed. Saez et al. (1990), Hermosila et al. (1983) and Costa (1992) described a similar spermiogenesis. Spermatids with a longish nucleus sustained by Sertoli Cells with ovoid nucleus were observed in L. catesbeianus, commonly observed in espermatozoid feixes/bundles in which the cyst was already open. This showed that the cyst opens up before the spermatozoids were ready, probably during a more advanced spermiogenesis stage. The final maturation occurred in the lumen of the seminiferous tubules.

Andrade et al. (2001), studying fish, found similar Sertoli cell nuclei as in the present study, varying from triangular to rounded, without however specifying in which situation each one of the shapes occurred. Fraile et al. (1990) verified a reduction of the Sertoli Cells during spermatogenesis of marbled newt (Triturus marmoratus). In L. catesbeianus the Sertoli Cells presented an opposite pattern.

For Triturus marmoratus Fraile et al. (1992) found nucleus diameters of $13.4 \mu \mathrm{m}$ for ISPG, $12.2 \mu \mathrm{m}$ for IISPG, $15.3 \mu \mathrm{m}$ for ISPC, $12.4 \mu \mathrm{m}$ for IISPC and $12.2 \mu \mathrm{m}$ for SPT. In the present study, the values decreased from the largest cells, which were primary spermatogonia, to the smallest that were spermatids.

Saez et al. (1990) described the diameter of IISPC in marbled newts as intermediate between the ISPC and the spermatids (SPT) diameters. This characteristic was observed in bullfrog as well.

For the Leydig cell of Polypedates maculatus, Kanamadi and Jirankali (1992) measured a nuclear diameter of $10 \mu \mathrm{m}$. This was nearly twice as high as the one found for bullfrog.

A measurement of the nucleolar diameter of the Sertoli cell was important since it was observed that treatments could reduce it. Matta et al. (2002) observed a reduction in the nucleolar diameter of this cell when they treated Nile tilapia with goitrogen drugs.

Ko et al. (1998) found an area of $0.6 \mathrm{~mm}^{2}$ of the seminiferous tubule for Rana dybowskii and of 0.3 $\mathrm{mm}^{2}$ for $R$. rugosa and $R$. nigromaculata. The 
diameter of the seminiferous tubule of $L$. catesbeianus was more similar to the value of $R$. dybowskii, which is around $0.54 \mathrm{~mm}^{2}$.

The cyst size in the different cell types varied slightly, since cell quantity and size varied as well. Once the primary spermatocides are the largest cells of the spermatogenic lineages, it is perfectly acceptable that their cysts are slightly larger. This would not be the case if cells were not lost in the meiotic divisions. The diameters of the different cyst types have not yet been recorded for fish or amphibia.

Fraile et al. (1989) found a proportion of $12 \%$ interstitium and $88 \%$ seminiferous tubule for Bufo bufo gredosicola. This was very similar for $L$. catesbeianus (13.8\% intertubule and $86.2 \%$ tubule) and similar to other vertebrate classes such as rodents and carnivores.

The different cysts found in the seminiferous tubules have been quantified and qualified by several authors. Kanamadi and Jirankali (1992) found around five spermatid cysts per tubule and as many primary spermatogonium and secondary spermatocide cysts. Five to ten cysts per tubule were found for primary spermatocides in Polypedates maculatus frogs. For the Chinese bullfrog ( $R$. rugulosa) Kao et al. (1993) described a mean of 4 ISPG cysts, 3.5 secondary spermatogonium and 4 ISPC cysts and less than one cyst per tubule for IISPC and SPT. KO et al. (1998) found around 2 ISPG, 9 IISPG, 3.5 ISPC, 2 IISPC cysts and 1.7 SPT cyst per tubule in $R$. nigromaculata. For $R$. rugosa, the number of cysts was 2.7 in ISPG, 7 in IISPG, 3 in ISPC and 1.5 cysts in IISPC and SPT. In $R$. dybowskii 5 ISPG, 8 IISPG of and 2 ISPC cysts were observed, but no IISPC and SPT cysts.

Generally, L. catesbeianus has a proportionally similar number of cysts to those found in $R$. nigromaculata, $R$. rugosa and $R$. dybowskii. Interestingly the spermatid and secondary spermatocide cysts are normally of small occurrence in these four frog species. This fact can be explained by the fact that IISPC is a short period of the meiosis, unlike the case of the spermatids.

Leydig cells are generally mononucleated in most animals studied and their nucleus, generally round or ovoid, is localized eccentrically with one to three nucleoli (Setchell, 1991). These cells are important owing to their pronounced androgen production (Bardin, 1996) and they are essentially relevant for the spermatogenesis patterns since they participate in their organization. These cells are important owing to their pronounced androgen production (Bardin, 1996) and they are essentially relevant for the spermatogenesis patterns since they participate in their organization. Kanamadi and Jirankali (1992) found a greater number of Leydig cells, close to the collecting ducts in $P$. maculatus. In L. catesbeianus, Leydig cells were observed in great quantity close to the blood vessels. According to Fraile et al. (1990), the Leydig cells cluster in form of a glandular tissue towards the end of spermiogenesis, which is called interstitial gland by Saez et al. (1992). In $L$. catesbeianus the Leydig cells also appear separately.

In bullfrogs, the proportion nucleus - cytoplasm volume in the Leydig cell showed that the nucleus was the largest component of this cell in relation to its cytoplasm in the period in which the animals were collected. This could be due to a lower a hormone production of this cell in the sampling period, resulting in a lower cytoplasm activity. The hormones could act before the study period, which could cause cytoplasm size variations in this cell throughout the year.

To supply an adequate number of spermatogenic cells per Sertoli Cells the regulation of the number of germinative cells usually occurs during the spermatogonial stage, although apoptoses of spermatocides are common in mammals during the meiotic division stages (França and Russell, 1998; De Rooij and Russell, 2000). Apoptoses play a very important role in the homeostasis during spermatogenesis, and influence the speciesspecific sperm production directly (Sharpe, 1994; França and Russell, 1998; Sinha Hikim and Swerdloff, 1999). The meiotic index indicated a loss of $37 \%$ during the meiotic process from this ISPC to SPT, in other words, only about 2.5 were formed for a number of four expected spermatids, somewhat similar to observations in Tilapia niolotica where losses attained 40\% (Matta, 2000). In mammals these losses are normally about $25 \%$ (França and Russell, 1998). A variation of 5 to $68 \%$ was however observed in the different species studied so far. These data indicated that the control mechanisms of apoptoses during the meiosis existed in this form since fishes might have been conserved during the evolution of the vertebrates.

Considering indifferentiated and differentiated spermatogonia, three to nine mitotic divisions are necessary in mammals to form primary 
spermatocides (França and Russell, 1998). According to Callard and Callard (1999), the number of mitotic divisions of spermatogonia is species-specific, varying from four to 14 divisions in vertebrates and 13 in Squalus acanthias. In teleosts, a spermatogonial stem cell would produce primary spermatocides after five or six divisions in Brachydanio rerio, after nine or ten divisions in Oryzias latipes and ten divisions in Anguilla japonica (Miura et al., 1991; Miura, 1999). Ten to 12 divisions and 14 divisions, respectively, are necessary in Gambusia affinis and Poecilia reticulata (Billard, 1986) while in Tilapia nilotica at least 10 divisions occur before the meiotic process begins (Matta, 2000). The bullfrog fits in this range, with 8 generations of spermatogonia until the beginning of meiosis. Still, it is not clear whether the number of mitotic divisions is an inherent property of stem spermatogonium, or if it is controlled by environmental factors, or by both (Miura, 1999).

It could be concluded that the spermatogenesis of bullfrog fitted in the pattern of other captivity Anurans, with differences as the morphology of Sertoli and Leydig cells nuclei. This study would fill a gap in the field of testicular morphometry of L. catesbeianus, whereas the gonadal morphology of bullfrogs has already been described by several authors (Sprando and Russell, 1988; Costa, 1992; Chavadej et al., 2000; Sasso-Cerri et al, 2004).

\section{RESUMO}

A morfometria é uma importante ferramenta para a biologia estrutural, permitindo estudos estereológicos e análises quantitativas. Existem muitos pontos a serem esclarecidos sobre a morfometria testicular desta espécie, que objetivamos desvendar neste trabalho. Quinze machos adultos foram estudados, em período chuvoso e de fotoperíodo longo (dezembro, 2000). $\mathrm{O}$ IGS encontrado foi de $0.15 \%$. O diâmetro nuclear das células germinativas e da célula de Leydig, o diâmetro nucleolar das células de Sertoli e a área dos cistos e túbulos foram determinados. O número médio de ISPC, IISPC e SPT por cisto e o número médio de cisto por túbulo foi estimado. A proporção nucleoplasmática do núcleo da célula de Leydig foi de $76.22 \%$, indicando pouca atividade citoplasmática. Oito gerações de espermatogônia foram estimadas. A eficiência da espermatogênese na meiose e mitose foi de $63 \%$ e
49\%, respectivamente. A espermatogênese de rãtouro segue os padrões dos demais Anuros de cativeiro, apresentando diferenças nos núcleos das células de Sertoli e Leydig.

\section{REFERENCES}

Andrade, R. F.; Bazzoli, N.; Rizzo, E.; Sato, Y. (2001), Continuos gametogenesis in the neotropical freswater teleost, Bryconops affinis (Pisces: Characidae).- $T$. and Cell, 33 (5), 524-532.

Bardin, C. W. (1996), Androgens: early attempts to evaluate Leydig cell function in man. In: Payne, A. H., Hardy, M. P., Russell, L. D, eds. The Leydig cell. Cache River Press, Viena. pp.31-42

Billard, R. (1986), Spermatogenesis and spermatology of some teleost fish species. Reprod Nutr Dev, 26, 877-920.

Bozzola, J. J.; Russell, L. D (1998), Electron Microscopy. $2^{\mathrm{a}}$ Ed. Jones and Bartlett Pub.,Boston. pp.320-339

Callard, G. V.; Callard, I. P. (1999), Spermatogenesis in Nonmammals. In: Knobil, E., Neill, J. D. Encyclopedia of Reproduction, vol 4. Academic Press, San Diego. pp.563-570..

Chavadej, J.; Jerareungrattana, A.; Sretarugsa, P. and Sobhon, P. (2000), Structure and development of the testis of bullfrog, Rana catesbeiana, and their changes during seasonal variation. ScienceAsia, 26, 69-80.

Costa, C. L. S. (1992), Desenvolvimento do Aparelho Reprodutor e Fatores Associados ao Ciclo Reprodutivo da Rã-Touro no Sistema Anfigranja. MSc thesis, Universidade Federal de Viçosa, Viçosa, Brazil.

De Rooij, D.G. ; Russell, LD. (2000), All you wanted to know about spermatogonia but were afraid to ask. $J$ Androl 21 (6),776-98.

Dubois, A. (2007), Naming taxa from cladograms: A cautionary tale. Mol Phylo Evo 42, 317-330.

Fontanello, D. ; Soares, H. A.; Mandelli Jr, J.; Santos, L. E.; Penteado, L. A.; Campos, B. E. S.; REIS, J. M. (1984), Estação de reprodução de Rana catesbeiana (Shaw,1982), criados em ranário comercial e influência de fatores climáticos sobre o número de desovas. Bol. Inst. Pesca, 11, 123-130.

Fraile, F.; Saez, F.J., Codesal, J. And Paniagua, R. (1992), Characterisation of secondary spermatocytes in the marbled newt (Triturus marmoratus). J. Anat, 180, 81-88.

Fraile, F.; Saez, F. J. ; Paniagua, R. (1990), The cycle of follicular and intersticial cells (leydig cells) in the testis of the marbled newt, Triturus marmoratus (Caudata, Salamandridae). J. of Morph., 204, 89-101.

Fraile, F.; Paniagua, R.; Rodriguez, M. C.; Saez, F.J. (1989), Effect of photoperiod on testicular fuction in 
blinded and non-blindede marbled newts, Triturus marmoratus (Caudata, Salamandridae). J. of Morph, 200,151-162.

Fraile, F.; Paniagua, R.; Saez, F. J.; Rodriguez, M. C.; Lizana, M. (1989), Immunocytochemical and quantitative study of interstitial cells in the high mountain toad Bufo bufo gredosicola during the spermatogenic cycle. Herp. J, 1, 330-335.

França, L. R.; Russell, L. D. (1998), The testis of domestic mammals. In: Martínez-Garcia F, Regadera J, eds. Male reproduction: a multidisciplinary overview. Churchill Communications, Madrid. pp.198-219.

Hermosila, I. B.; Coloma, S. L.; Wetgert, T. G.; Reyest, E. Gome, O. V. (1983), Espermatogénesis en la rana chilena Caudiverbera caudiverbera (Linné, 1758) (Anuro, Leptodactylidae). Bol. Soc. Biol. Concepción Chile, 54, 103-115.

Kao, Y-I; Alexander, P. S.;Yang,V. V. C.; Yu, Y-L. (1993), Annual patterns of testicular development an activity in the chinese bullfrog (Rana rugulosa). Zool. Sci., 10, 337-351.

Kanamadi, R. D.; Jirankali, S. S. (1992), Testicular activity in Polypedates maculatus : seasonal changes in spermatogenesis and fat bodies.- J. Herp., 26(3), 329-335.

Ko, S. K.; Kang, H. M.; Im, W-B.;Kwon, H. B. (1998), Testiculas cycles in three species of korean frogs: Rana nigromaculata, Rana rugosa and Rana dybowskii. G. Comp. End., 111, 347-358.

Lima, S. L; Agostinho, C.A. (1995), A tecnologia da criação de rãs. Impr. Univ, Viçosa. pp18-24.

Lima, S. L; Agostinho, C.A. 1988. A criação de rãs. Ed. Globo, Rio de Janeiro, pp 47-51.

Mandarim-De-Lacerda, C.A. (1995), Métodos Quantitativos em Morfologia. EDUERJ, Rio de Janeiro. pp 72-114.

Matta, S. L. P.; Vilela, D. A. R.; Godinho, H. P.; França, L. R. (2002), The goitrogen 6-n-propyl-2thiouracil (PTU) given during testis development increases Sertoli and germ cells numbers per cyst in fish: the tilapia (Oreochromis niloticus) model. Endocrinology, 143(3), 970-978.

Matta, S. L. P. (2000), Efeitos do hipotiroidismo induzido pelo PTU (6-n-propil-2-tiouracil) sobre a proliferação das células germinativas em tilápia (Oreochromis niloticus). DSc thesis, Federal University of Minas Gerais, Belo Horizonte, Brazil.

Miura, T. (1999), Spermatogenetic cycle in fish. In: Knobil E, Neill JD. Encyclopedia of reproduction, vol 4. Academic Press, San Diego. pp.571-578

Miura, T.; Yamauchi, K.; Takahashi, H.; Nagahama, Y. (1991), Hormonal induction of all stages of spermatogenesis in vitro in the male japanese eel (Anguilla japonica). Proc. Natl. Acad. Sci. U.S.A, 88, 5774-5778.
Pierantoni, R.; Gobbelis,G.; Meccarielo, R.; Palmiero, C.; Fienga, G.; Minnuci,S.; Fasano,S. (2002), The amphibian testis as model to study germ cell progression during spermatogenesis. Comp.Bioc. and Fis. , 132, 131-139.

Pierantoni R. (1999), Male reproductive system, amphibians. In: Knobil E, Neill JD, eds. Encyclopedia of reproduction, vol. 3. Academic Press, New York, pp. 10-15.

Sadleir, R. M. F. S. (1973). Amphibians. In: The reproduction of vertebrates. Academic Press, New York, pp.36-52.

Saez, F. J.; Fraile, B.; Miguel, M. P. and Paniagua, R. (1992), Effects of low temperature on testicular cells in the marbled newt, Triturus marmoratus (Caudata, Salamandridae). Herpetological Journal, 2, 125-132.

Saez, F.J.; Fraile, B.; Paniagua, R. (1990), Histological and quantitative changes in the annual testicular cycle of Triturus marmoratus marmoratus .-Can. J. Zool., 68, 63-72.

Sasso-Cerri, E.; Faria, F.P.; Freymuller, E., Miraglia, S.M. (2004), Testicular Morphological Changes During the Seasonal Reproductive Cycle in the Bullfrog. Journal of experimental zoology, 30(1A), 249-260.

Setchell, B. P. (1991), Male reproductive organs and semen. In: CUPPS, P. T. Reproduction in Domestic Animals, $4^{\text {th }}$ ed. Academic Press, San Diego. pp. 221250

Sharpe, R. M. (1994), Regulation of spermatogenesis. In: Knobil E, Neil JD, Greenwald GS, Markert CL, Pfaff DW, eds. The physiology of reproduction, vol 1. Raven Press, New York. pp.363-1434.

Sinha, H. A. P.; Swerdloff, R. S. (1999), Hormonal and genetic control of germ cell apoptosis in the testis. Rev Reprod, 4(1), 38-47.

Sprando, R. L.; Russel, L. D. (1988), Spermiogenesis in the bullfrog (Rana catesbeiana): a study of cytoplasmic events including cell volume changes and cytoplasmic elimination. J Morphol, 198 (3), 303-19.

Sprando, R. L; Russel, L. D. (1987), A comparative study of Serttoli cell ectoplasmic specializations in select non-mammalian vertebrates. -Tis. and cell., 19 (4), 479-493.

Vizotto, L. D. (1986), Ranicultura brasileira. Bol Assoc. Nac. Ran. $\mathrm{N}^{\mathrm{O}} \mathbf{4}$.
Received: May 02, 2007; Revised: May 05, 2008; Accepted: April 22, 2009. 